\title{
Estimates of genetic parameters of pigments and agronomic traits in green and purple lettuce
}

\section{Estimativas de parâmetros genéticos para pigmentos e caracteres agronômicos em alface verde versus roxa}

\section{Alisson Henrique Gama de Oliveira ${ }^{1 *} \mathbb{D}$, Gabriel Mascarenhas Maciel ${ }^{2}$, Ana Carolina Silva Siquieroli ${ }^{2} \mathbb{D}$, Ana Carolina Pires Jacinto ${ }^{2}$, Aline José da Silveira ${ }^{2} \mathbb{D}$, Ernani Clarete da Silva $\mathbb{B}^{\mathbb{D}}$}

\author{
1Universidade Federal de Uberlândia/UFU, Uberlândia, MG, Brasil \\ 2Universidade Federal de Uberlândia/UFU, Monte Carmelo, MG, Brasil \\ 3Universidade Federal de São João Del-Rei/UFSJ, Sete Lagoas, MG, Brasil \\ *Corresponding author: agralisson@gmail.com \\ Received in May 23, 2019 and approved in August 21, 2019
}

\begin{abstract}
Understanding genetics and the gene interactions involved in the expression of certain characteristics becomes a determining factor for better exploration of its use. The development of breeding programs that combine one or more desirable trait into a single cultivar is directly impacted by this lack of knowledge of the genetic bases involved. The objective of the present study was to estimate the genetic parameters involved in pigment expression and agronomic characteristics in lettuce. Parental evaluations of lettuce, $P_{1}$ (green) and $P_{2}$ (purple) parental generations, the segregating generations $F_{1}$ and $F_{2^{\prime}}$ and the backcrosses $B C_{1}$ and $B_{2}$ originating from the UFU-Crespa199\#1\#1 $\times$ UFU-Albina\#2 crossing were evaluated. The chlorophyll and anthocyanin contents, number of leaves and plant diameter were evaluated. The study was conducted by testing all generations and the estimates obtained by averages and variances. Indications of polygenic or oligogenic inheritance were verified by the characteristic number of leaves, plant diameter, and anthocyanin content. The complete and additive-dominant models satisfactorily explained the performance of the variables, except the anthocyanin content.
\end{abstract}

Index terms: Anthocyanin; genetic interactions; segregating generations.

\begin{abstract}
RESUMO
O entendimento da genética e das interações gênicas envolvidas na expressão de determinadas características se torna um fator determinante para a melhor exploração seu uso. Este desconhecimento das bases genéticas envolvidas impacta diretamente no desenvolvimento de programas de melhoramento que aliem uma ou mais características desejáveis em uma única cultivar. O objetivo do presente estudo foi estimar os parâmetros genéticos envolvidos na expressão dos pigmentos e características agronômicas em alface. Foram avaliados parentais $\mathrm{P}_{1}$ (verde) e $\mathrm{P}_{2}$ (roxo), as gerações segregantes $F_{1}$ e $F_{2^{\prime}}$ e os backcross $B c_{1}$ e $B c_{2}$ originados do cruzamento UFU-Crespa199\#1\#1 x UFU-Albina\#2. As avaliações foram feitas para teor de clorofila, teor de antocianina, número de folhas e diâmetro de planta. O estudo foi realizado pelo teste de gerações e as estimativas obtidas por meio das médias e variâncias. Foi verificado indicativo de herança poligênica ou oligogênica para as características número de folhas, diâmetro de plantas e teor de antocianina. Com exceção do teor de antocianina tanto o modelo completo quanto o aditivo-dominante explicaram satisfatoriamente o comportamento das variáveis.
\end{abstract}

Termos para indexação: Antocianina; interações gênicas; gerações segregantes.

\section{INTRODUCTION}

Lettuce (Lactuca sativa L.) is the most important leafy green vegetable in Brazil and in the world (Brzezinski et al., 2017; Yuri et al., 2017). According to Queiroz, Cruvinel and Figueiredo (2017), the current lettuce crop area in Brazil occupies approximately 35,000 hectares, and approximately $60 \%$ of the national market is occupied by cultivars that have curly lettuce leaves (Valeriano et al., 2016).
In the past decade, a large number of studies have shown the importance of plant pigments and, more specifically, those in lettuce crops. The anthocyanin pigment has great antioxidant activity and acts in the prevention of a large number of diseases (Rocha, 2015; Figueiredo; Lima, 2015). In plant tissues, the coloration from orange-red to blue-violet is determined by the presence of anthocyanin (Dai et al., 2016). 
Chlorophyll is another plant pigment that is found in greater concentrations in leafy green vegetables (Silva et al., 2014). In addition to the direct relationship with the photosynthetic activity, the chlorophyll content also presents a high correlation with the content of carotenoids, having a correlation on the order of 0.81 (Cassetari et al., 2015), which directly influences leaf color and consequently influences consumer preference (Taiz; Zeiger, 2013; Silva; Ferreira; Ferreira, 2016).

The presence of the red color in the leaves of lettuce, according to Ryder (1999), is controlled by two genes, $C$ and $G$, which are influenced by an allelic $R$ series that is responsible for the distribution pattern of anthocyanin in the leaf. There are also reports of the influence of the gene "intensifier" $(I)$, which intensifies the shade of red in the leaf (Lindqvist, 1960).

In relation to agronomic traits, lettuce plants with a great number of leaves and plants of small diameter are desirable for the market. The junction of these characteristics results in plants with compact architecture, which reflects ease of handling, transportation and yield in industry processes (Santos et al., 2011; Ferreira et al., 2013; Resende et al., 2017). However, the development of commercial cultivars that hold all desirable characteristics in a single genotype is hampered by limited knowledge of the parameters that rule the mode of genetic inheritance of the main agronomic traits and leaf pigments in lettuce.

The knowledge of the genetic basis responsible for the expression of certain characteristics is of great importance in the conduction of a genetic improvement program, which allows for the prediction of the performance of hybrids and segregant generations (Cardoso et al., 2015). The analysis of the genetic relationships of the $P_{1}$, $\mathrm{P}_{2}, \mathrm{~F}_{1}, \mathrm{~F}_{2}, \mathrm{Bc}_{1}$ and $\mathrm{Bc}_{2}$ generations is important to assess the adequacy of the additive-dominant model and its ability to estimate the genetic parameters of certain characteristics (Rocha et al., 2009). Thus, the objective of this study was to estimate genetic parameters for chlorophyll and anthocyanin content, for the number of leaves and for plant diameter in green and purple loose-leaf lettuce.

\section{MATERIAL AND METHODS}

The experiment was conducted from February 2017 to June 2018 at the Experimental Station of Vegetables of the Universidade Federal de Uberlândia (UFU), Campus Monte Carmelo, MG (18 $42^{\circ} 43.19^{\prime} \mathrm{N}, 47^{\circ} 29^{\prime} 55.8^{\prime \prime} \mathrm{W}$, at an altitude of $873 \mathrm{~m}$ ).

On February $20^{\text {th }}$ (2017), two genotypes from the Tropicalized Biofortified Lettuce Breeding Program of the
UFU were sown, with the genotype UFU-Albina\#2 (male parent presenting green leaf coloring) and the genotype UFU-Crespa199\#1\#1 (female parent presenting purple leaf coloring), to obtain the $\mathrm{F}_{1}$ generation (UFU-Albina\#2 $\times$ UFU-Crespa199\#1\#1). On September $22^{\text {nd }}(2017)$, the $F_{1}$ generation (UFU-Crespa199\#1\#1 $\times$ UFU-Albina\#2) and the parental $P_{1}$ and $P_{2}$ were sown to obtain the $F_{2}$ generation, which was backcrossed with both parents.

On March 23 ${ }^{\text {rd }}$ (2018), the generations $\mathrm{P}_{1}, \mathrm{P}_{2}, \mathrm{~F}_{1}$, $\mathrm{F}_{2}, \mathrm{Bc}_{1}$ and $\mathrm{Bc}_{2}$ were sown. After 50 days, the plants were transplanted to field conditions and spaced by 0.25 $\times 0.25 \mathrm{~m}^{-1}$. Prior to the installation of the experiment, soil samples were collected at $0-20 \mathrm{~cm}$ soil depths and analyzed in the Laboratory of Soil Fertility of the UFU. The physicochemical analysis presented the following results: loamy texture ( $>50 \%$ clay); $\mathrm{pH} \mathrm{CaCl}_{2}=4.9$; soil organic matter $=3.9 \mathrm{dag} \mathrm{kg}^{-1} ; \mathrm{P}(\mathrm{rem})=79.1 \mathrm{mg} \mathrm{dm}^{-3} ; \mathrm{K}$ $=0.29 \mathrm{cmol} \mathrm{dm}^{-3} ; \mathrm{Ca}=3.3 \mathrm{cmolc} \mathrm{dm}^{-3} ; \mathrm{Mg}=1.3 \mathrm{cmolc}$ $\mathrm{dm}^{-3}, \mathrm{H}+\mathrm{Al}=4.9 \mathrm{cmolc} \mathrm{dm}^{-3}$; base sum $=4.90 \mathrm{cmolc} \mathrm{dm}^{-3}$; $\mathrm{CEC}=9.80 \mathrm{cmolc} \mathrm{dm}^{-3}$; base saturation $=50 \%$.

The experimental design used was the analysis of generations. The climatic conditions of the period 12 May 2018 to 22 June 2018 are shown in Figure 1:

After the plants reached commercial standards (91 days after sowing), the following variables were evaluated:

Anthocyanin concentration: The extraction followed the methodology proposed by Francis (1982). Lettuce plants were ground, and samples of 0.5 grams were collected and added to $10 \mathrm{~mL}$ of an extraction solution (ethanol $95 \%+$ hydrochloric acid $1.5 \mathrm{~mol} \mathrm{~L}^{-1}$ in 85:15 proportions). The samples were homogenized and packaged in the total absence of light in B.O.D. (biochemical oxygen demand), with a constant temperature of $25{ }^{\circ} \mathrm{C}$ for 24 hours. The sample absorbances were read in triplicate in a UV-Visible Digital Mod. GTA-96 spectrophotometer at $535 \mathrm{~nm}$. The results were expressed in $\mathrm{mg}$ of total anthocyanins per $100 \mathrm{~g}$ of sample, according to the formula:

$A t=(A b s * f) / \varepsilon$

where At $=\mathrm{mg}$ anthocyanins per $100 \mathrm{~g}$ of fresh mass; Abs $=$ absorbance $; \mathrm{f}=$ dilution factor; $\varepsilon=$ coefficient of molar absorptivity of cyanidin (98.2).

Number of leaves: The number of leaves with a length equal to or greater than $5 \mathrm{~cm}$ were manually counted.

Plant diameter: The plant diameter $(\mathrm{cm})$ was obtained by measuring the distance between the edges of the plants with the aid of a graduated ruler. 


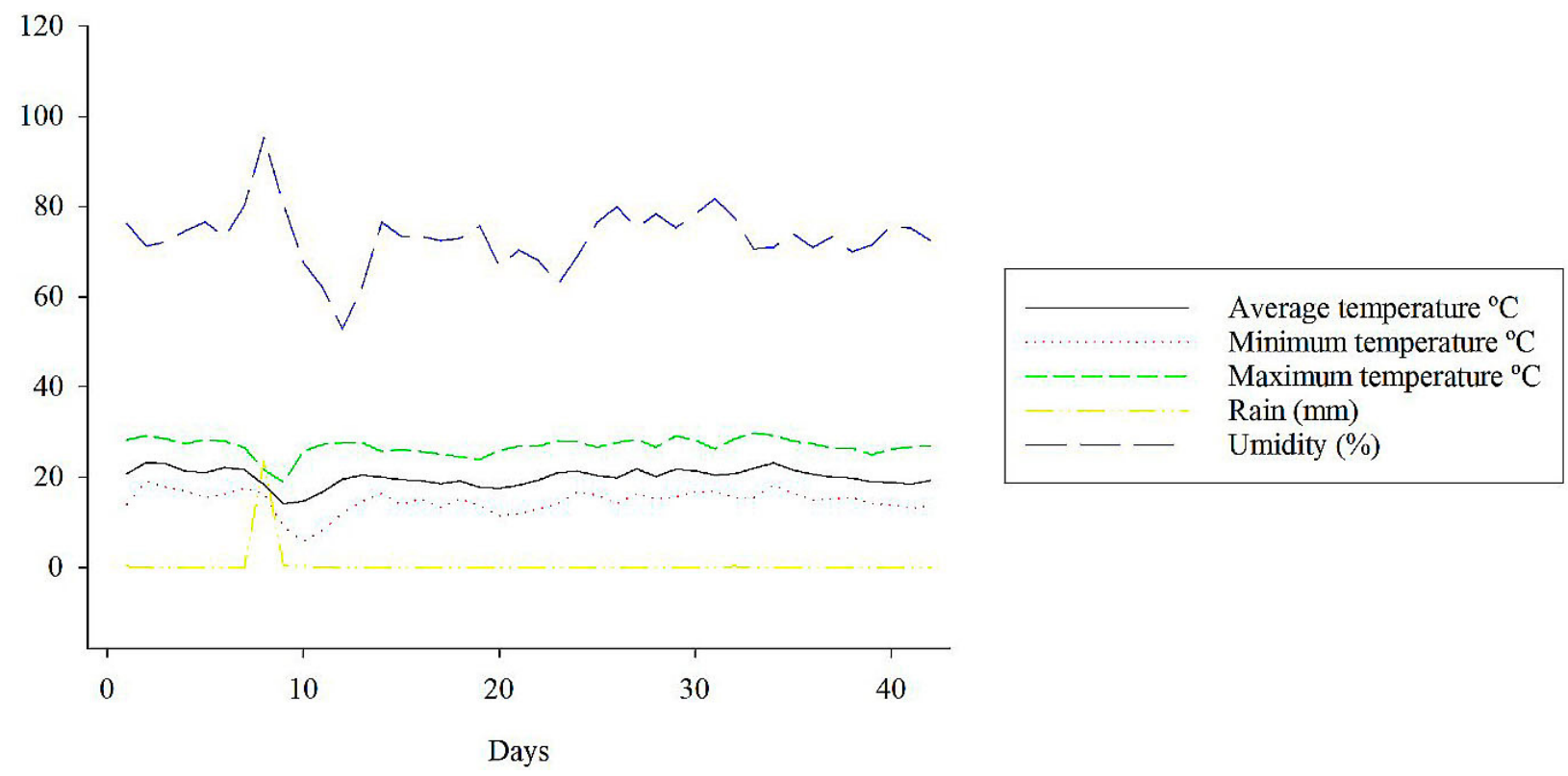

Figure 1: Climatic conditions in Monte Carmelo-MG during the period from May $12^{\text {th }}$ (2018) until June $22^{\text {nd }}$ (2018). Source: Cooxupé.

Chlorophyll content: Chlorophyll content was measured in a leaf located in the middle of the lettuce plant with the aid of a portable chlorophyll meter (Minolta SPAD-502 CFL1030).

Genetic-statistical analyses were performed using the program Genes v.2013.5.1 (Cruz, 2013), from which the following parameters were obtained: genetic variance in $\mathrm{F}_{2}\left(\sigma_{g}^{2}\right)$, environmental variance in $\mathrm{F}_{2}\left(\sigma_{m}^{2}\right)$, phenotypic variance in $\mathrm{F}_{2}\left(\sigma_{f}^{2}\right)$, additive variance in $\mathrm{F}_{2}\left(\sigma_{a}^{2}\right)$, variance due to deviations of dominance in $\mathrm{F}_{2}\left(\sigma_{d}^{2}\right)$, broad-sense heritability $\left(h_{b}^{2}\right)$, narrow-sense heritability $\left(h_{n}^{2}\right)$, average degree of dominance based on averages $(\mathrm{K})$, the minimum number of genes $(\eta)$, average $(m)$ epistatic variance additive $\times$ additive type (aa), epistatic variance additive $x$ dominant type $(\mathrm{ad})$ and epistatic variance dominant $x$ dominant type (dd). These parameters are mathematically expressed as follows:

Genetic variance in $\mathrm{F}_{2}$ :

$\sigma_{\mathrm{g}\left(\mathrm{F}_{2}\right)}^{2}=\sigma_{\mathrm{f}\left(\mathrm{F}_{2}\right)}^{2}-\sigma_{\mathrm{m}\left(\mathrm{F}_{2}\right)}^{2}$

Environmental variance in $\mathrm{F}_{2}$ :

$\sigma_{\mathrm{m}\left(\mathrm{F}_{2}\right)}^{2}=\frac{\mathrm{VM}_{\mathrm{P}_{1}}+\mathrm{VM}_{\mathrm{P}_{2}}+2 \mathrm{VM}_{\mathrm{F}_{1}}}{4}$
Phenotypic variance in $\mathrm{F}_{2}$ :

$$
\sigma_{\mathrm{f}\left(\mathrm{F}_{2}\right)}^{2}=\sigma_{\mathrm{F}_{2}}^{2}
$$

Additive variance in $\mathrm{F}_{2}$ :

$$
\sigma_{\mathrm{a}}^{2}=\frac{1}{2} \mathrm{a}^{2}=2 \sigma_{\mathrm{g}\left(\mathrm{F}_{2}\right)}^{2}-\left[\sigma_{\mathrm{g}\left(\mathrm{BC}_{1}\right)}^{2}+\sigma_{\mathrm{g}\left(\mathrm{BC}_{2}\right)}^{2}\right]
$$

where:

$$
\begin{aligned}
& \sigma_{\mathrm{g}\left(\mathrm{BC}_{1}\right)}^{2}=\sigma_{\mathrm{f}\left(\mathrm{BC}_{1}\right)}^{2}-\sigma_{\mathrm{m}\left(\mathrm{BC}_{1}\right)}^{2} \\
& \sigma_{\mathrm{g}\left(\mathrm{BC}_{2}\right)}^{2}=\sigma_{\mathrm{f}\left(\mathrm{BC}_{2}\right)}^{2}-\sigma_{\mathrm{m}\left(\mathrm{BC}_{2}\right)}^{2}
\end{aligned}
$$

Variance due to deviations of dominance in $\mathrm{F}_{2}$ :

$$
\sigma_{d}^{2}=\frac{1}{4} d^{2}=\sigma_{g\left(F_{2}\right)}^{2}-\sigma_{a}^{2}
$$

Broad-sense heritability:

$$
h_{b}^{2}=\frac{\sigma_{g\left(F_{2}\right)}^{2}}{\sigma_{f\left(F_{2}\right)}^{2}}=\frac{\sigma_{g\left(F_{2}\right)}^{2}}{\sigma_{g\left(F_{2}\right)}^{2}+\sigma_{m\left(F_{2}\right)}^{2}}
$$




$$
\begin{gathered}
\text { Narrow-sense heritability: } \\
\mathrm{h}_{\mathrm{n}}^{2}=\frac{\sigma_{\mathrm{a}\left(\mathrm{F}_{2}\right)}^{2}}{\sigma_{\mathrm{f}\left(\mathrm{F}_{2}\right)}^{2}}=\frac{\sigma_{\mathrm{a}\left(\mathrm{F}_{2}\right)}^{2}}{\sigma_{\mathrm{a}\left(\mathrm{F}_{2}\right)}^{2}+\sigma_{\mathrm{d}\left(\mathrm{F}_{2}\right)}^{2}+\sigma_{\mathrm{m}\left(\mathrm{F}_{2}\right)}^{2}}
\end{gathered}
$$

Average degree of dominance based on averages:

$\mathrm{K}=\frac{2 \overline{\mathrm{F}_{1}}-\left(\overline{\mathrm{P}_{1}}+\overline{\mathrm{P}_{2}}\right)}{\overline{\mathrm{P}_{1}}-\overline{\mathrm{P}_{2}}}$

where $\overline{\mathrm{F}_{1}}, \overline{\mathrm{P}_{1}}$ and $\overline{\mathrm{P}_{2}}$ are averages of the progenitors $\mathrm{F}_{1}, \mathrm{P}_{1}$ and $\mathrm{P}_{2}$, respectively.

Minimum number of genes involved in determining the character:

$\eta=\frac{\mathrm{R}^{2}\left(1+0.5 \mathrm{~K}^{2}\right)}{8 \sigma_{\mathrm{g}}^{2}}$

where $\mathrm{R}$ is the amplitude between the averages of parents, or $\mathrm{R}=\mathrm{P}_{1}-\mathrm{P}_{2}$.

Estimation of effects:

$\hat{\mathrm{m}}=\frac{1}{2} \overline{\mathrm{P}}_{1}+\frac{1}{2} \overline{\mathrm{P}}_{2}+4 \overline{\mathrm{F}}_{2}-2 \overline{\mathrm{BC}}_{1}-2 \overline{\mathrm{BC}}_{2}$

$\hat{\mathrm{a}}=\frac{1}{2} \overline{\mathrm{P}}_{1}+\frac{1}{2} \overline{\mathrm{P}}_{2}$

$\hat{\mathrm{d}}=-\frac{3}{2} \overline{\mathrm{P}}_{1}-\frac{3}{2} \overline{\mathrm{P}}_{2}-\overline{\mathrm{F}}_{1}-8 \overline{\mathrm{F}}_{2}+6 \overline{\mathrm{BC}}_{1}-6 \overline{\mathrm{BC}}_{2}$ $\widehat{\mathrm{aa}}=-4 \overline{\mathrm{F}}_{2}+2 \overline{\mathrm{BC}}_{1}+2 \overline{\mathrm{BC}}_{2}$

$\widehat{\mathrm{ad}}=-\overline{\mathrm{P}}_{1}+\overline{\mathrm{P}}_{2}+2 \overline{\mathrm{BC}}_{1}-2 \overline{\mathrm{BC}}_{2}$

$\widehat{\mathrm{dd}}=\overline{\mathrm{P}}_{1}+\overline{\mathrm{P}}_{2}+2 \overline{\mathrm{F}}_{1}+4 \overline{\mathrm{F}}_{2}-4 \overline{\mathrm{BC}}_{1}-4 \overline{\mathrm{BC}}_{2}$

\section{RESULTS AND DISCUSSION}

The averages observed in generations $\mathrm{P}_{1}$ and $\mathrm{P}_{2}$ for all variables enabled the observation of the contrast necessary for the accomplishment of the study (Table 1). The averages observed in generations $F_{1}$ and $F_{2}$ for the content of chlorophyll and anthocyanin were intermediate to the averages observed in parents. According to Ribeiro, Boiteux and Santos (2014), these results may be an indication of an additive allelic nature.

The occurrence of transgressive segregants was observed for most characteristics, except for the chlorophyll content. In accordance with Laurindo et al. (2017), the occurrence of transgressive segregants highlights the occurrence of different alleles among parents and still allows for the selection of superior individuals for the characteristic.

The genetic variance was superior to the environmental variance observed for all variables analyzed in the present study, with the exception of the anthocyanin content (Table 2). These results are in accordance with Azevedo et al. (2014), who evaluated genetic parameters relating the same characteristics to early flowering and obtained estimates of genetic variance above the environmental variances. This result indicates that the genetic factors have a greater influence on the expression of the characteristic than the environmental factors and allows for the selection of individuals with characteristic expressions above the average (Publio Júnior et al., 2018).

Table 1: Number of plants evaluated, agronomic characterization and contents of pigments in the generations $\mathrm{P}_{1}, \mathrm{P}_{2}, \mathrm{~F}_{1}, \mathrm{~F}_{2}, \mathrm{BC}_{1}$, and $\mathrm{BC}_{2}$ derived from the UFU-Crespa199\#1\#1 $\times$ UFU-Albina\#2 cross.

\begin{tabular}{cccccc}
\hline Generation & NP & NL & CLF & DMT & ANT \\
\hline $\mathrm{P}_{1}$ & 20 & 11.95 & 19.03 & 20.46 & 12.31 \\
$\mathrm{P}_{2}$ & 20 & 19.95 & 44.38 & 29.15 & 52.71 \\
$\mathrm{~F}_{1}$ & 20 & 21.10 & 40.25 & 29.22 & 43.46 \\
$\mathrm{~F}_{2}$ & 203 & 15.45 & 36.41 & 23.43 & 22.83 \\
$\mathrm{Bc}_{1}$ & 18 & 15.50 & 30.38 & 21.58 & 15.52 \\
$\mathrm{Bc}_{2}$ & 20 & 21.30 & 40.89 & 30.27 & 32.57 \\
Transgressive & - & Yes & No & Yes & Yes \\
\hline
\end{tabular}

$\mathrm{NP}=$ number of plants; NL = number of leaves; $\mathrm{CLF}=$ chlorophyll content; $\mathrm{DMT}$ = plant diameter; $\mathrm{ANT}=$ anthocyanin content. 
Table 2: Estimates of genetic parameters obtained from the variances of agronomic traits evaluated in plants of the generations $P_{1}, P_{2}, F_{1}, F_{2}, B C_{1}$ and $B C_{2}$ derived from the UFU-Crespa199\#1\#1 $\times$ UFU-Albina\#2 cross.

\begin{tabular}{ccccc}
\hline Parameters & $\mathrm{NL}$ & $\mathrm{CLF}$ & DMT & ANT \\
\hline$\sigma_{\mathrm{g}}^{2}$ & 12.83 & 19.09 & 12.76 & -32.12 \\
$\sigma_{\mathrm{e}}^{2}$ & 7.26 & 18.14 & 10.24 & 183.50 \\
$\sigma_{\mathrm{f}}^{2}$ & 20.08 & 37.23 & 23.00 & 151.38 \\
$\sigma_{\mathrm{a}}^{2}$ & 17.98 & -2.58 & 14.73 & 123.41 \\
$\sigma_{\mathrm{d}}^{2}$ & -5.16 & 21.68 & -1.98 & -155.53 \\
$\mathrm{~h}_{\mathrm{b}}^{2}$ & 63.86 & 51.28 & 55.47 & -21.22 \\
$\mathrm{~h}_{\mathrm{n}}^{2}$ & 89.56 & -6.94 & 64.06 & 81.52 \\
$\mathrm{~K}$ & -1.28 & -0.67 & -1.02 & -0.54 \\
$\mathrm{H}$ & 4.34 & -51.06 & 5.73 & 6.21 \\
\hline
\end{tabular}

$\sigma_{\mathrm{g}}^{2}=$ genotypic variance in $\mathrm{F}_{2} ; \sigma_{\mathrm{e}}^{2}=$ environmental variance in $\mathrm{F}_{2} ; \sigma_{\mathrm{f}}^{2}=$ phenotypic variance in $\mathrm{F}_{2} ; \sigma_{\mathrm{a}}^{2}=$ additive variance in $\mathrm{F}_{2} ; \sigma_{\mathrm{d}}^{2}$ = variance due to deviations of dominance; $h_{b}^{2}=$ broad-sense heritability; $h_{n}^{2}=$ narrow-sense heritability; $K=$ average degree of dominance based on averages; $\eta=$ minimum number of genes involved in the expression of the character; $\mathrm{NL}=$ number of leaves; $\mathrm{CLF}=$ chlorophyll content; DMT = plant diameter; $\mathrm{ANT}=$ anthocyanin content.

The estimates of variance for the number of leaves and plant diameter indicated that the genotypic variance in the $\mathrm{F}_{2}$ population was attributed to the additive effects, observing that the variances assigned to deviations of dominance were negative $\left(\sigma_{\mathrm{d}}^{2}=-5.16\right.$ and -1.98 for number of leaves and plant diameter, respectively). This result was not observed for the other variables, in which the genetic variance was predominantly attributed to deviations of dominance. According to Cruz (2010), the additive variance reflects the heritable fraction of genetic variance, becoming a determinant factor to obtain gains in selection.

Estimates of narrow-sense heritability found in this study may be considered high for the number of leaves and plant diameter $\left(\mathrm{h}_{\mathrm{n}}^{2}=89.56\right.$ and 64.06 , respectively). These estimates were close to those found by Azevedo et al. (2014), who evaluated 11 lettuce cultivars and found estimates of narrow-sense heritability of 59.39 and $96.77 \%$ for the number of leaves and plant diameter, respectively.

The anthocyanin content showed high estimative heritability. According to Ferreira et al. (2011), the anthocyanin content is more desirable when associated with predominantly additive effects for the characteristic. However, such a result was not observed for the anthocyanin content.

The estimate of the average degree of dominance for the content of chlorophyll and anthocyanin content indicated the existence of partial dominance $(K=-0,67$ and $-0,54$ for the chlorophyll and anthocyanin contents, respectively). For the plant diameter, the estimate of the average degree of dominance was close to 1 , while the number of leaves presented an estimate of $\mathrm{K}$ above 1 (1.28), which indicates complete dominance and overdominance of gene action, respectively.

The number of genes involved in the expression of the characteristic number of leaves, plant diameter and anthocyanin content were determined by 5, 6 and 7 genes, respectively. For the chlorophyll content, the estimate was inconclusive. The estimated performance provided evidence of a polygenic or oligogenic nature for these characteristics. Specifically, for the approximate number of genes that control the content of anthocyanin, the results corroborate the classical work of Ryder (1999), which identified 6 genes governing the expression of anthocyanin in lettuce leaves.

In Table 3, the estimates of genetic parameters obtained by the complete model and the additive-dominant model are presented. The additive effect was not significant for any of the characteristics. For the number of leaves and plant diameter, the effect due to deviations of dominance (D) and the epistatic interactions of the type additive $\times$ dominant showed a significant effect, and the interactions between epistatic dominant $\times$ dominant type (dd) was important for the anthocyanin content. 
In the additive-dominant model, the average and the standard deviation of dominance were significant for the number of leaves, chlorophyll content and plant diameter as determined by the $t$-test at $5 \%$ probability. For the variable anthocyanin content, only the average presented significant effects.

In the complete model, the additive effect was the most important for the four characteristics evaluated (Table 4), explaining $62.64,89.86,52.70$ and $86.75 \%$ of all variability in $\mathrm{F}_{2}$. Moreira et al. (2013) demonstrated that obtaining homozygous superior genotypes becomes possible in these characteristics in populations derived from $\mathrm{F}_{2}$.

For the additive-dominant model, the parameter $\mathrm{m}$ largely explained the variation observed in the $\mathrm{F}_{2}$ population, explaining $90.13,85.71,94.03$ and $71.05 \%$ of the variation observed for number of leaves, chlorophyll content, plant diameter, and anthocyanin content, respectively. The additive effects were of secondary importance in the present study, explaining $26.93 \%$ of the variation observed in the anthocyanin content.

Analyzing the averages observed and estimated averages, with the exception of the anthocyanin content, the data adjusted to the additive-dominant model enabled high estimates of the quotient of correlation (r), reaching values of $0.91,0.99$ and 0.94 for plant diameter, chlorophyll content and number of leaves, respectively (Figure 2).

Table 3: Estimates of genetic parameters of four agronomic traits evaluated in plants of the generations $\mathrm{P}_{1}, \mathrm{P}_{2^{\prime}} \mathrm{F}_{1^{\prime}}$ $\mathrm{F}_{2}, \mathrm{BC}_{1}$ and $\mathrm{BC}_{2}$ derived from the UFU-Crespa199\#1\#1 $\times$ UFU-Albina\#2 cross.

\begin{tabular}{ccccccccc}
\hline \multirow{2}{*}{ Parameter } & \multicolumn{3}{c}{$\mathrm{NL}$} & \multicolumn{2}{c}{ CLF } & \multicolumn{2}{c}{ DMT } & \multicolumn{2}{c}{ ANT } \\
\cline { 2 - 9 } & CM & ADM & CM & ADM & CM & ADM & CM & ADM \\
\hline $\mathrm{m}$ & $4.14 \mathrm{~ns}$ & $14.83^{*}$ & $34.82^{*}$ & $31.60^{*}$ & $14.83^{*}$ & $22.82^{*}$ & $27.67^{*}$ & $29.58^{*}$ \\
$\mathrm{a}$ & $-4.00 \mathrm{~ns}$ & $-4.50 \mathrm{~ns}$ & $-12.67 \mathrm{~ns}$ & $-12.43 \mathrm{~ns}$ & $-4.34 \mathrm{~ns}$ & $-5.65 \mathrm{~ns}$ & $-20.20 \mathrm{~ns}$ & $-17.66 \mathrm{~ns}$ \\
$\mathrm{~d}$ & $28.26^{*}$ & $4.47^{*}$ & $0.95 \mathrm{~ns}$ & $8.89^{*}$ & $20.02^{*}$ & $4.26^{*}$ & $-35.16 \mathrm{~ns}$ & $-9.53 \mathrm{~ns}$ \\
$\mathrm{aa}$ & $11.80^{\star}$ & - & $-3.11 \mathrm{~ns}$ & - & $9.97^{*}$ & - & $4.84 \mathrm{~ns}$ & - \\
$\mathrm{ad}$ & $-3.60 \mathrm{~ns}$ & - & $4.31 \mathrm{~ns}$ & - & $-8.69 \mathrm{~ns}$ & - & $6.30 \mathrm{~ns}$ & - \\
$\mathrm{dd}$ & $-11.31 \mathrm{~ns}$ & - & $4.48 \mathrm{~ns}$ & - & $-5.63 \mathrm{~ns}$ & - & $50.95^{*}$ & - \\
\hline
\end{tabular}

$\mathrm{m}$ : average of all possible homozygous genes; a: average of additive effects; $\mathrm{d}$ : measure of the dominance deviations; aa: average of all additive $\times$ additive interactions; ad: average of all additive $\times$ dominant interactions; dd: average of all dominant $\times$ dominant interactions; NL = number of leaves; CLF = chlorophyll content; DMT = plant diameter; ANT = anthocyanin content; * significant at 95\% confidence; ns = not significant; CM: complete model; ADM: additive-dominant model.

Table 4: Coefficients of determination $\left(R^{2}, \%\right)$ by nonorthogonal decomposition of the sum of the squares of adjusted parameters in the complete model (CM) and additive-dominant model (ADM) of the generations $\mathrm{P}_{1}, \mathrm{P}_{2^{\prime}}$ $\mathrm{F}_{1}, \mathrm{~F}_{2}, \mathrm{BC}_{1}$ and $\mathrm{BC}_{2}$ derived from the UFU-Crespa199\#1\#1 $\times$ UFU-Albina\#2 cross.

\begin{tabular}{|c|c|c|c|c|c|c|c|c|}
\hline \multirow{2}{*}{ Parameters } & \multicolumn{2}{|c|}{$\mathrm{NL}$} & \multicolumn{2}{|c|}{ CLF } & \multicolumn{2}{|c|}{ DMT } & \multicolumn{2}{|c|}{ ANT } \\
\hline & $\mathrm{CM}$ & ADM & $\mathrm{CM}$ & ADM & $\mathrm{CM}$ & ADM & $\mathrm{CM}$ & ADM \\
\hline $\mathrm{m}$ & 2.04 & 90.13 & 9.84 & 85.71 & 22.33 & 94.03 & 6.45 & 71.05 \\
\hline a & 62.64 & 7.43 & 89.86 & 12.84 & 52.70 & 4.93 & 86.75 & 26.93 \\
\hline$d$ & 12.09 & 2.43 & 0 & 1.45 & 5.08 & 1.03 & 1.28 & 2.01 \\
\hline Subtotal & 76.80 & 99.99 & 99.70 & 100 & 80.11 & 99.99 & 94.48 & 99.99 \\
\hline aa & 22.07 & - & 0.08 & - & 10.47 & - & 0.20 & - \\
\hline ad & 2.35 & - & 0.17 & - & 8.51 & - & 0.38 & - \\
\hline$d d$ & 5.65 & - & 0.04 & - & 0.90 & - & 4.93 & - \\
\hline Epistatic effect & 30.1 & - & 0.29 & - & 19.88 & - & 5.51 & - \\
\hline
\end{tabular}

$\mathrm{m}$ : average of all possible homozygous genes; a: average of additive effects; $\mathrm{d}$ : measure of the dominance deviations; aa: average of all additive $\times$ additive interactions; ad: average of all additive $\times$ dominant interactions; dd: average of all dominant $\times$ dominant interactions; $\mathrm{NL}=$ number of leaves; $\mathrm{CLF}=$ chlorophyll content; $\mathrm{DMT}=$ plant diameter; $\mathrm{ANT}=$ anthocyanin content; CM: complete model; ADM: additive-dominant model. 

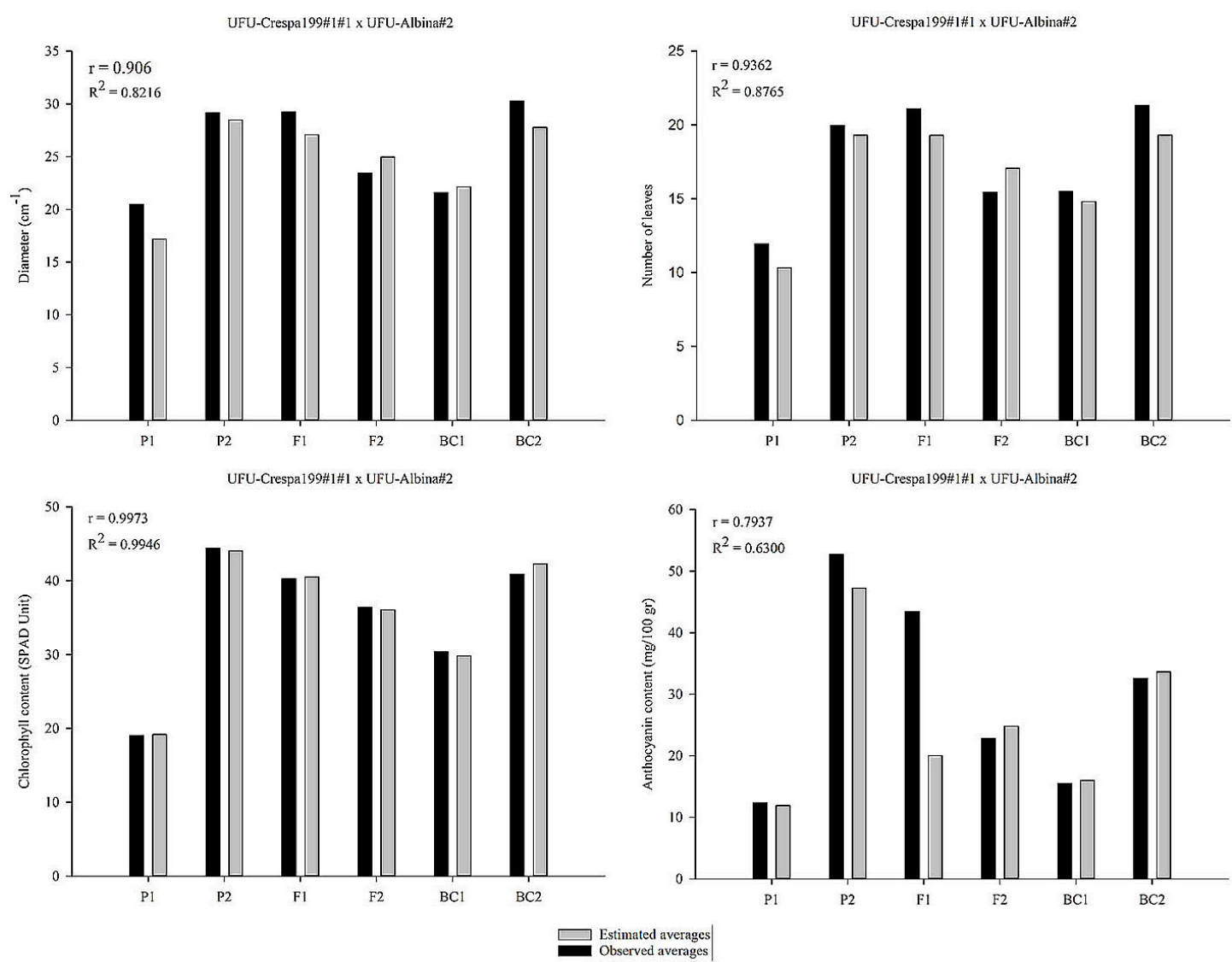

Figure 2: Averages observed and expected for each of the generations in the additive-dominant model for four agronomic traits from the UFU-Crespa199\#1\#1 x UFU-Albina\#2 cross.

\section{CONCLUSIONS}

The results observed for the number of leaves, plant diameter and anthocyanin content indicate that a polygenic or oligogenic pattern is responsible for these characteristics. The gene interactions involved in the expression of the chlorophyll and the anthocyanin contents are predominantly the partial dominance type, while the gene interaction appears to be a complete dominance and overdominance for plant diameter and number of leaves, respectively. The detection of segregating individuals for the number of leaves, plant diameter and anthocyanin content indicates the possibility of selecting superior individuals.

\section{REFERENCES}

AZEVEDO, A. M. et al. Parâmetros genéticos e análise de trilha para o florescimento precoce de características agronômicas da alface. Pesquisa Agropecuária Brasileira, 49(2):118-124, 2014.
BRZEZINSKI, C. R. et al. Produção de cultivares de alface americana sob dois sistemas de cultivo. Revista Ceres, 64(1):83-89, 2017.

CARDOSO, D. L. et al. Análise dialélica de Hayman de características relacionadas à produção e a qualidade de frutos em mamoeiro. Bragantia, 74(4):394-399, 2015.

CASSETARI, L. S. et al. $\beta$-carotene and chlorophyll levels in cultivars and breeding lines of lettuce. Acta Horticulturae, 1083(1):469-473, 2015.

CRUZ, C. D. Princípios de genética quantitativa. 2. ed. Viçosa: Editora UFV, 2010. 394p.

CRUZ, C. D. GENES - A software package for analysis in experimental statistics and quantitative genetics. Acta Scientiarum. Agronomy, 35(3):271-276, 2013.

DAI, W. et al. Genetic analysis for anthocyanin and chlorophyll contents in rapeseed. Ciência Rural, 46(5):790-795, 2016. 
FERREIRA, S. et al. Identificação de linhagens avançadas de alface quanto à resistência a Meloidogyne javanica. Ciência e Agrotecnologia, 35(2):270-277, 2011.

FERREIRA, L. L. et al. Comportamento de variedades de alface na semeadura de março no município de Areia-PB. Scientia Plena, 9(4):1-6, 2013.

FIGUEIREDO, F. J.; LIMA, V. L. A. G. Antioxidant activity of anthocyanins from quixabeira (Sideroxylon obtusifolium) fruits. Revista Brasileira de Plantas Medicinais, 17(3):473-479, 2015.

FRANCIS, F. J. Analysis of anthocyanins. In: MARKAKIS, P. (ed.). Anthocyanins as food colors. New York: Academic Press, 1982. p.181-207.

LAURINDO, R. D. F. et al. Potencial de híbridos e populações segregantes de abóbora para teor de óleo nas sementes e plantas com crescimento do tipo moita. Revista Ceres, 64(6):582-591, 2017.

LINDQVIST, K. On the origin of cultivated lettuce. Hereditas 46(3-4):319-350, 1960.

MOREIRA, G. R. et al. Herança de caracteres de resistência por antixenose de Solanum pennellii à traça-do-tomateiro em cruzamento com 'Santa Clara'. Horticultura Brasileira, 31(4):574-581, 2013.

PUBLIO JÚNIOR, E. et al. Estimativas de parâmetros genéticos em genótipos de feijão-frade. Revista de Ciências Agrárias, 41(3):806-814, 2018.

QUEIROZ, A.; CRUVINEL, V.; FIGUEIREDO, K. Produção de alface americana em função da fertilização com organomineral. Enciclopédia Biosfera, 14(25):1053-1063, 2017.

RESENDE, G. M. et al. Adaptação de genótipos de alface crespa em condições semiáridas. Revista Brasileira de Agricultura Irrigada, 11(1):1145-1154, 2017.
RIBEIRO, H. L. C.; BOITEUX, L. S.; SANTOS, C. A. F. Genetic parameters of earliness and plant architecture traits suitable for mechanical harvesting of cowpea (Vigna unguiculata). Australian Journal of Crop Science, 8(8):1232-1238, 2014.

ROCHA, M. M. et al. Controle genético do comprimento do pedúnculo em feijão-caupi. Pesquisa Agropecuária Brasileira, 44(3):270-275, 2009.

ROCHA, S. M. B. M. Benefícios funcionais do açaí na prevenção de doenças cardiovasculares. Journal of Amazon Health Science, 1(1):1-10, 2015.

RYDER, E. J. Lettuce, endive and chicory. New York: CABI Publishing, 1999. 208p.

SANTOS, D. et al. Produção comercial de cultivares de alface em bananeiras. Horticultura Brasileira, 29(4):609$612,2011$.

SILVA, M. A. et al. Pigmentos fotossintéticos e índice SPAD como descritores de intensidade do estresse por deficiência hídrica em cana-de-açúcar. Bioscience Journal, 1(30):173181, 2014.

SILVA, E.; FERREIRA, E. A.; FERREIRA, M. R. Desempenho da alface americana sob a aplicação de adubos químico e orgânico. Ciencia Et Praxis, 9(18):21-24, 2016.

TAIZ, L.; ZEIGER, E. Fisiologia Vegetal. 5. ed. Porto Alegre: Artmed, 2013. 954p.

VALERIANO, T. T. B. et al. Alface americana cultivada em ambiente protegido submetida a doses de potássio e lâminas de irrigação. Irriga, 21(3):620-630, 2016.

YURI, J. E. et al. Desempenho agronômico de genótipos de alface americana no Submédio do Vale do São Francisco. Horticultura Brasileira, 35(2):292-297, 2017. 